\title{
An Investigation of Students, Parents and Teachers' Satisfaction in Science High Schools in Konya Province in Terms of Some Variabilities
}

\author{
Suleyman Alpaslan Sulak (Corresponding author) \\ Department of Educational Sciences, Necmettin Erbakan University \\ Ahmet Kelesoglu Faculty of Education, Program of Curriculum and Instruction, Konya, \\ Turkey \\ Tel: 90-332-323 8220 E-mail: suleymansulak@gmail.com
}

Kemal Tutuncu

Department of Electrical and Electronics Engineering, Selcuk University

Faculty of Technology, Program of Electronic, Konya, Turkey

Tel: 90-332-2233335_E-mail: ktutuncu@selcuk.edu.tr

Murat Koklu

Department of Computer Engineering, Selcuk University

Faculty of Technology, Program of Computer Software, Konya, Turkey

Tel: 90-332-2233335_E-mail: mkoklu@selcuk.edu.tr

Received: April 21, 2018

doi:10.5296/jet.v5i2.13308
Accepted: June 29, 2018

Published: July 16, 2018

URL: http://dx.doi.org/10.5296/jet.v5i2.13308

\begin{abstract}
Education is the most decisive factor in the success of people in life and work. Today expectations in education have changed. Increases in education levels and facility of ways to access information have differentiated our level of social consciousness. Educational expectations of parents and teachers have also changed. There is now a mass who feign reluctance more and have a higher expectation from the school. Teachers' expectations of students are also increasing. Researches examining the effects of school variables on student achievement have increased in recent years. Many studies indicate that schools with desirable characteristics have positive effects on student achievement. There are a large number of components that make the school environment come to life. Classroom sizes at schools, school culture, teaching methods used by teachers and professional qualifications are some of them. These components affect the satisfaction levels of teachers and parents working in schools. The aim of this research is to examine the satisfaction of teachers, students and students' parents in Meram Science High School, Selçuklu Science High School and Karatay
\end{abstract}


Science High School in terms of some variables in Konya province. Satisfaction scale was developed by researchers. Conducting a literatüre survey,the researchers have found that there were 46 questions and 3 open ended questions for the Student Satisfaction Scale, 45 questions in 3 sections including 5 demographic questions, 37 questionnaires and 3 open ended questions for the Parent Satisfaction Scale; For the Teacher Satisfaction Scale, 3 demographic questions, 43 scale questionnaires and 5 open-ended questions, the scales were finalized with 51 questions in 3 sections. When the answers given by the students are examined, the school satisfaction ratings were determined as undecided. When the answers given by the parents were examined, the school satisfaction level was partially determined as agreeing. When the answers given by the teachers were examined, the school satisfaction level was determined as strongly agreeing.

Keywords: Parent satisfaction, Student satisfaction, Teacher satisfaction, Science schools

\section{Introduction}

Rapid social and technological changes and developments that we have experienced in our age have begun to push the schools to become dynamic organizations that are open to change and innovation, integrating with their surroundings in the way of continuous development. When school is considered as a system, it is seen that school and family relation is one of school subsystems. School and family relations have a significant impact on achieving their goals in the efficient operation of the school system. Changing this effect in favour of the school and the environment will be possible with the work of both sides again. While the school and the family try to fulfill the duties specified in the regulation in the best way, the school administration should also prepare suitable environments for it (Aydin, 2004).

Schools can not be thought of separately from society and family. Achievement of the schools'goals will be possible with the participation of the student, the parents, and the school staff in the formal education process. Participation of parents in the education process will increase parental satisfaction. Parents' satisfaction determines the direction of service in education (Çınkır \& Nayır, 2017). The most important goal of establishing quality schools is to provide teachers, parents and students with satisfaction. Schools should focus on the teachers, students and parents who make up the three most important backbones of the school. The more they are satisfied, the higher the quality in education.

Education is not just a school process. One of the most important factors in out-of-school education is the families. Therefore, there should be a good cooperation between the family and the school. Parent-teacher and parent-school administration relations need to be increased. Parental expectations are constantly changing. School administration needs to do what is necessary to meet these expectations. Thus, parental satisfaction will be ensured. This satisfaction will ensure the formation of school culture and develop continuously. The influence of the parents on the education of the students is undeniable. Major tasks are being undertaken by the parents, administrators and teachers in order to increase student success.

Continuous training programs should be prepared for parents and students as those who are working in schools and benefiting from school. This will ensure that an established school culture is formed. Only the contributions of the employees or beneficiaries won't be sufficient for the formation of school culture. School staff, pupils and parents need to do their 
part to embrace and implement activities to create school cultures (Hargreaves, 2012; Wetland, 2016). School culture will also improve quality at the same time. Teacher, student and parent satisfaction are important factors in this process. The fact that the teachers,parents and students are involved in the decision mechanism will contribute to the good operation of the system and thus the formation of the school culture and the increase of the quality will be inevitable (Y1lmaz \& Yildırım, 2017).

Every feature and condition that the school has has an impact on the class climate. It was determined that there was an interaction between the socio-economic status of the school where the school was located, the number of students in the school, the duration of the teacher's stay in the class and student success. The environment in which the school is located affects the physical structure of the school, the social facilities of the school, and the expectations and performances of the students and the teachers. The physical structure of the school, such as laboratory, classroom, canteen, sports hall, cafeteria and hostel, should be appropriate to the development characteristics and needs of the students (Başar, 2014; Schleicher, 2015)

The relationship between school size and student achievement was found to be inversely and linearly correlated with achievement in schools with less than four-hundreds of students in the research conducted, with a greater success rate than schools with a higher intensity. It is considered that student satisfaction level from the school and the quality of the education will increase depending on the places outside the classroom (laboratory, sports hall, canteen, cafeteria, board etc.)as long as they are sufficient for the use of the students (Dean \& Gibbs, 2015).

The increase in the satisfaction of teachers and students and the high level of moral will be primarily due to a democratic environment in school administration and to ensuring that teachers, parents and students have knowledge of the school decisions and have a voice about appropriate issues. (Başar, 2014; Shann, 1998)

The student's happiness in the class is ensured by his active involvement in the process. All developed countries are looking for ways to educate their students according to their abilities, with the idea that raising and maintaining their prosperity depends on everyone's ability to use their potential at the optimum level. (Özden, 2010).

In setting up the educational environment, teachers need to create activities that will motivate the students in their relations to the students. If the student is motivated, the satisfaction of the student for the lesson, the teacher and the school will progress positively. Students are the most logical assessors of the class, school and school management. The facilities that the school has and the effective use of these are the factors that increase student satisfaction (Douglas et al, 2006; Balc1, 2013; Aldridge \& Fraser, 2016).

Self-reliance (1994) attitude; is identified as an emotional readiness or tendency, in the form of accepting or rejecting a certain person, group, institution or idea. Positive student attitudes increase performance.

The increse in the student satisfaction will provide a positive change in the attitude of student and increase the success.

Students are highly affected by the physical environment. In the educational setting, the 
physical environment is made up of school buildings and their attachments. There are many studies on the positive effect of the improved physical environment on student achievement (Barbra, 2006; Bullock, 2007)

Teacher success and performance is also related to teacher satisfaction. Satisfaction is the feeling of satisfaction that the job gives to the individual. Satisfaction is one of the most important conditions for people to be successful, happy and productive (Göktaş, 2007). Satisfaction is also a matter of functional purpose. There is a positive relationship between satisfaction and success, and dissatisfaction and changing school. Students who are dissatisfied with their school will have a high rate of changing school. Students who are not satisfied with the school have high school change rates. According to researches, there is a positive relationship between the physical sufficiency of schools and student achievement (Corcoran, White, \& Whitburn, 2015; Clark, 2002)

This research is important as it determines the satisfaction levels of the students and the parents from schools, tries to find out which aspects of schools are strong, which aspects are weak, which aspects should be improved, and presents the proposals regarding these issues.

The aim of this research is to examine the satisfaction of the pupils, parents and teachers working in science high schools in Konya.

\section{Material and Method}

\subsection{Method}

A survey model was used in the study. Survey models are research approaches that aim to describe the past or present situation as it exists (Karasar, 2007). The aim of this research is to measure the satisfaction level of teachers who work in science high schools in Konya, students and their parents.

\subsection{Working Universe and sample}

The universe of the work consists of students, parents and teachers working in Selçuklu, Meram and Karatay Science High Schools in Konya. There are 27 teachers in the teacher sample and 142 parents in the parent sample. It wasn't needed to take samples for students because it is possible to have access to all of the students.

\subsection{Data Collection Tools}

"Teacher Satisfaction Scale" consisting of 3 demographic features, 43 items of 5 likert type items and 5 open-ended questions was used by the researchers to measure teachers' satisfaction. "Student Satisfaction Scale" consisting of 46 items of 5 likert type and 3 open ended questions developed by the researchers was used to measure the satisfaction level of the students. The "Teacher Satisfaction Scale", consisting of 5 demographic features, 37 items of 5 likert type items and 3 open-ended questions, developed by the researchers, was used to measure satisfaction of the parents.

\subsection{Collection and Evaluation of Data}

The research was conducted between 01-28 February 2018. Percentage and frequency were used in the analysis of the data. Opinions of students, parents and teachers in each school in the scope of the research were taken, transferred to Excel environment and statistical studies were carried out. 


\section{Macrothink}

\section{Findings}

\subsection{Findings about teachers}

A total of 27 teachers participated in the research. Seventeen (63\%) male and $10(37 \%)$ female teachers participated in the study. The distribution of the teachers according to their genders is shown in the Table-1. Distribution of the teachers participating in the research according to the branches is shown in Table 2. Teachers participated in the research in Turkish Language and Literature (6), Physics and English (4), Chemistry (3), Geography (2), German, Physical Education, Biology, Religion Culture, Philosophy, Mathematics, Guidance and History. The distribution of the teachers according to their professional seniority is shown in Table-3. Teachers have 10-15 years of seniority (3), 15-20 years of seniority (13), 20-25 years of seniority (5), 25-30 years of seniority (3) and more than 30 years of seniority (3).

Table 1. Distribution of teachers according to gender

\begin{tabular}{|l|l|}
\hline Gender & Frequency \\
\hline Men & 17 \\
\hline Women & 10 \\
\hline
\end{tabular}

Table 2. Distribution of Teachers by Branches

\begin{tabular}{|l|l|}
\hline Branch & Frequency \\
\hline Turkish Language and Literature & 6 \\
\hline Physics & 4 \\
\hline English & 4 \\
\hline Chemistry & 3 \\
\hline Geography & 2 \\
\hline German & 1 \\
\hline Physical Education & 1 \\
\hline Biology & 1 \\
\hline Religious Culture & 1 \\
\hline philosophy & 1 \\
\hline Mathematics & 1 \\
\hline Guidance & 1 \\
\hline History & 1 \\
\hline
\end{tabular}

Table 3. Distribution of teachers according to their occupational seniority

\begin{tabular}{|l|l|}
\hline Seniority & Frequency \\
\hline $10-15$ Years & 3 \\
\hline $15-20$ Years & 13 \\
\hline 20-25 years & 5 \\
\hline 25-30 Years & 3 \\
\hline More than 30 years & 3 \\
\hline
\end{tabular}

Teachers' satisfaction scale consisted of 435 -point likert type scale items and 5 open-ended questions. Likert-type scales are graded as strongly disagree (1), disagree (2), undecided (3), agree (4) and strongly agree (5). The average of teachers' responses to scale items was found 
to be "I definitely agree" $(4,41)$. When they were examined on the basis of the material, they stated that they definitely participated in 33 items and 10 in others. The averages of responses given by scale items and teachers' scale items are shown in Table 4. The answers to the open ended questions are shown in Table 5.

Table 4. Average responses of teachers to scale items

\begin{tabular}{|c|c|c|c|}
\hline I.N & ITEMS & $\mathrm{X}$ & OPINION \\
\hline 1 & $\begin{array}{l}\text { I think that there is an adequate-healthy communication-sharing between the school } \\
\text { administration and the teachers }\end{array}$ & 4,44 & I strongly agree \\
\hline 2 & I think that our teachers are sufficient-healthy, communication-sharing among themselves. & 3,52 & I agree \\
\hline 3 & $\begin{array}{l}\text { I think that there is sufficient-healthy communication-sharing between our school's } \\
\text { Guidance Service and our school teachers. }\end{array}$ & 4,63 & I strongly agree \\
\hline 4 & Confidence in our school administrators. & 4,59 & I strongly agree \\
\hline 5 & Confidence in our teachers. & 4,22 & Absolutely agree \\
\hline 6 & Confidence in our school guidance service. & 4,70 & I strongly agree \\
\hline 7 & $\begin{array}{l}\text { School management takes account of our views on the solution of school problems and } \\
\text { school development. }\end{array}$ & 4,52 & I strongly agree \\
\hline 8 & Efforts are made to resolve the problems we have brought to School Administration. & 4,67 & Absolutely agree \\
\hline 9 & $\begin{array}{l}\text { I am informed enough about the studies related to the school (maintenance-repair, } \\
\text { project..) }\end{array}$ & 4,26 & Absolutely agree \\
\hline 10 & School roads and school services are safe. & 4,19 & Agree \\
\hline 11 & The physical conditions of our school are sufficient & 3,48 & I agree \\
\hline 12 & I would like to organize festivals that become traditional in terms of school culture. & 4,52 & I strongly agree \\
\hline 13 & Our school's library is adequate & 4,26 & I strongly agree \\
\hline 14 & I find the academic success of our school satisfactory & 4,59 & I strongly agree \\
\hline 15 & I find our school's social-cultural studies satisfactory & 4,19 & I agree \\
\hline 16 & $\begin{array}{l}\text { I find the projects within the scope of scientific and European Union in our school } \\
\text { satisfactory }\end{array}$ & 4,00 & I agree \\
\hline 17 & Our laboratories in our school are sufficient. & 3,96 & Agree \\
\hline 18 & $\begin{array}{l}\text { I think that STEM (Science-Technology-Engineering-Mathematics) Education studies } \\
\text { should be done in our school. }\end{array}$ & 4,30 & Absolutely agree \\
\hline 19 & $\begin{array}{l}\text { I think that our school should have laboratories related to the technology of the future } \\
\text { (robotics, automation, industry 4.0, manufacturing, etc.). }\end{array}$ & 4,85 & I strongly agree \\
\hline 20 & $\begin{array}{l}\text { I think that the technologically-based laboratories and classes should be established in } \\
\text { accordance with the projects we will develop on behalf of our school. }\end{array}$ & 4,74 & I strongly agree \\
\hline 21 & I am happy to be in this school & 4,67 & I totally agree \\
\hline 22 & I think our 9th grade students' level of readiness is sufficient. & 4,22 & Absolutely agree \\
\hline 23 & I find the communication between our teachers and our students adequate and healthy. & 4,59 & I strongly agree \\
\hline 24 & $\begin{array}{l}\text { I think that our teachers can pass on their savings to our students in an adequate and } \\
\text { healthy way }\end{array}$ & 4,70 & I strongly agree \\
\hline 25 & I think our students are treated equally and impartially & 4,63 & Strongly agree \\
\hline 26 & I think communication between the support staff and our students is adequate-healthy & 4,48 & I strongly agree \\
\hline 27 & I think that discipline works well in school & 4,70 & I strongly agree \\
\hline
\end{tabular}




\begin{tabular}{|l|l|l|l|}
\hline 28 & Reward and punishment are treated impartially and fairly. & 4,70 & Absolutely agree \\
\hline 29 & Basic moral values (righteousness, respect, justice, etc.) are gained in the school. & 4,74 & I strongly agree \\
\hline 30 & I think our school is always clean and well maintained & 4,44 & Strongly agree \\
\hline 31 & The school canteen is clean and healthy. & 4,56 & I strongly agree \\
\hline 32 & The school students' hostel is clean and well maintained. & 4,00 & Agree \\
\hline 33 & School meal is clean and healthy & 4,15 & I agree \\
\hline 34 & I find that extracurricular social-sports activities are adequate for our students . & 4,04 & I agree \\
\hline 35 & I think that our school's efforts towards environmental regulation are sufficient & 4,15 & I agree \\
\hline 36 & I think that our school will be able to come up with better points in a short time & 4,70 & I strongly agree \\
\hline 37 & Team spirit and integrity dominate at school & 4,22 & I strongly agree \\
\hline 38 & I find the school administration's work satisfactory & 4,74 & Strongly agree \\
\hline 39 & I find our teachers' work satisfactorily satisfactory & 4,33 & I strongly agree \\
\hline 40 & I find the work of the school guidance service satisfactory & 4,67 & Absolutely agree \\
\hline 41 & I find family parental work satisfactory & 4,26 & I strongly agree \\
\hline 42 & I find the school support staff's work satisfactory & 4,33 & I strongly agree \\
\hline 43 & Our teachers are happy to be in this school 4,78 & 4,78 & Strongly agree \\
\hline & Average & 4,41 & Absolutely agree \\
\hline
\end{tabular}

Table 5. Teachers' responses to open-ended questions

\begin{tabular}{|l|l|}
\hline 44 & $\begin{array}{l}\text { What do you most like about our school: } \\
\text { Student achievement level and quality (16), Physical conditions (5), Social activities (3) }\end{array}$ \\
\hline 45 & $\begin{array}{l}\text { What do you want your school to change? } \\
\text { Improvement of physical conditions (10), Improvement of laboratories (5), Improvement of pension and dining room } \\
(4), \text { Establishment of Z-library and conference room }\end{array}$ \\
\hline 46 & $\begin{array}{l}\text { What are your thoughts-suggestions for the increase of academic-social success in our school: } \\
(3), \text { Establishment of laboratories for new professions (2) Establishment of new laboratories for new professions (2) }\end{array}$ \\
\hline 47 & $\begin{array}{l}\text { In our school, Marker Lab, Industry } 4.0 \text { and so on. what are your thoughts about the establishment of an } \\
\text { innovative class / laboratory: } \\
\text { Absolutely must (24) }\end{array}$ \\
\hline 48 & $\begin{array}{l}\text { If there is anything else you want to indicate please write: } \\
\text { Physical conditions should be improved, Guidance activities should be increased, Foreign language lesson hours should } \\
\text { be increased }\end{array}$ \\
\hline
\end{tabular}

To the question "What do you most like in your schools?", teachers mostly responded that they like student success level and quality. They then expressed that they liked the school's physical conditions (5) and social activities (3). When we examine the features teachers want to change in their schools; they expressed those changes as improvement of the physical conditions (10), improvement of the laboratories (6), improvement of the hostel and the dining hall (5), and establishment of the Z-library and conference hall. As teachers' views on increasing academic and social achievement in their schools; they expressed their views as (8), the motivation of students (6), the joint trial exams (4), the simplification and effective use of curricula (3), and the establishment of laboratories for new professions (2). As for their 
views on Marker Lab Industry 4.0 and so on. in schools (24) most of them said that they should certainly be set up. When asked what other things teachers want to say; they expressed their views as improvement of physical conditions, increase of guidance activities and increase of foreign language hours.

\subsection{Findings about the students}

The Student Satisfaction Scale consists of 465 -point likert type scales and 3 open-ended questions. The averages of students' answers to the scale were calculated as "Undecided $(3,29) "$. When the answers given by the students to the scale items are examined; , "I do not agree (4)", "I am undecided (24)", "I agree" (16) and "I absolutely agree" (2). The student satisfaction scale and the average of the answers given by the students to the scale items are shown in Table 6 . The answers given by students to open-ended questions are shown in Table 7.

Table 6. Average of students' responses to scale items

\begin{tabular}{|l|l|c|l|}
\hline I.N & \multicolumn{1}{|c|}{ Items } & X & Opinion \\
\hline 1 & I can easily contact school administrators when I need them. & 3.15 & Indecisive \\
\hline 2 & I can easily contact the teachers when I need them. & 3.69 & Agree \\
\hline 3 & I can easily contact the guidance service when I need it & 3.49 & I agree \\
\hline 4 & $\begin{array}{l}\text { Efforts are made to solve problems that I communicate to my } \\
\text { teachers. }\end{array}$ & 3.46 & Agree \\
\hline 5 & $\begin{array}{l}\text { Efforts are made to resolve the problems I have faced with school } \\
\text { administration. }\end{array}$ & 2.88 & Indecisive \\
\hline 6 & I trust our adminisrators. & 3.11 & Indecisive \\
\hline 7 & I trust our teachers. & 3.76 & Agree \\
\hline 8 & $\begin{array}{l}\text { I can get guidance about my individual problems when I need } \\
\text { them. }\end{array}$ & 3.36 & Indecisive \\
\hline 9 & I can get guidance about efficient course work. & 3.26 & Indecisive \\
\hline 10 & Family pressure is a barrier to success in my classes. & 2.47 & Disagree \\
\hline 11 & School roads and school services are safe. & 3.01 & Indecisive \\
\hline 12 & I feel safe in school. & 3.45 & Agree \\
\hline 13 & I feel safe around the school. & 2.92 & Indecisive \\
\hline 14 & Physical conditions are sufficient for our school & 2.48 & Disagree \\
\hline 15 & I would like to have a gym in our school & 4.18 & Agree \\
\hline 16 & I would like to have a pool at our school & 3.83 & Agree \\
\hline 17 & $\begin{array}{l}\text { I would like to organize festivals that will become traditional in } \\
\text { terms of school culture. }\end{array}$ & 4.25 & $\begin{array}{l}\text { Absolutely } \\
\text { agree }\end{array}$ \\
\hline 18 & Our school's library is adequate & 2.75 & Indecisive \\
\hline 19 & Our views at our school are taken into account in our decisions. & 2.71 & Indecisive \\
\hline 20 & Our teacher asks for our opinions about students in class & 3.44 & Agree \\
\hline 21 & $\begin{array}{l}\text { When we have a health problem, the necessary sensitivity is } \\
\text { shown. }\end{array}$ & 3.55 & Agree \\
\hline 22 & I think that our classroom sizes need to be smaller. & 3.08 & Indecisive \\
\hline
\end{tabular}




\begin{tabular}{|c|c|c|c|}
\hline 23 & Lessons are taught in accordance with the level. & 3.34 & Indecisive \\
\hline 24 & In our school, guidance is given about career prospects & 3.01 & Indecisive \\
\hline 25 & The laboratories in our school are sufficient. & 2.59 & Disagree \\
\hline 26 & $\begin{array}{l}\text { I think that } r \text { STEM } \\
\text { (Science-Technology-Engineering-Mathematics) Education studies } \\
\text { should be carried out in our school. }\end{array}$ & 4.10 & Agree \\
\hline 27 & $\begin{array}{l}\text { I think that our school should have laboratories related to the } \\
\text { technology of the future (robotics, automation, industry } 4.0 \text { and } \\
\text { manufacturing, etc.). }\end{array}$ & 4.23 & $\begin{array}{l}\text { Absolutely } \\
\text { agree }\end{array}$ \\
\hline 28 & $\begin{array}{l}\text { I think that the technological base labs and classes should be } \\
\text { established in accordance with the projects we will develop on } \\
\text { behalf of our school. }\end{array}$ & 4.14 & Agree \\
\hline 29 & $\begin{array}{l}\text { I think that the information I have at school will be useful for my } \\
\text { life now or in the future. }\end{array}$ & 3.11 & Indecisive \\
\hline 30 & I think 30 school lessons are difficult. & 3.34 & Indecisive \\
\hline 31 & There are sufficient studies for university exams. & 3.13 & Indecisive \\
\hline 32 & The University entrance system worries me. & 3.76 & Agree \\
\hline 33 & I can easily ask my teachers what I do not understand. & 3.52 & Agree \\
\hline 34 & I can express my views and suggestions easily. & 3.55 & Agree \\
\hline 35 & Students are treated equally and impartially & 3.02 & Indecisive \\
\hline 36 & The school is always clean and well maintained. & 2.98 & Indecisive \\
\hline 37 & I can find the products I need in school canteen & 3.55 & Indecisive \\
\hline 38 & The school canteen is clean and healthy. & 3.53 & Agree \\
\hline 39 & $\begin{array}{l}\text { The school boarding house is clean and well maintained. (only on } \\
\text { board) }\end{array}$ & 2.76 & Indecisive \\
\hline 40 & The school's dining room is clean and healthy & 2.77 & Indecisive \\
\hline 41 & There are as many social and cultural activities in the school. & 2.28 & Disagree \\
\hline 42 & $\begin{array}{l}\text { Assessment of exam results (oral and written examinations) is } \\
\text { impartial. }\end{array}$ & 3.56 & Agree \\
\hline 43 & Reward and punishment are treated impartially and fairly. & 3.32 & Indecisive \\
\hline 44 & $\begin{array}{l}\text { Basic moral values (righteousness, respect, justice, etc.) are gained } \\
\text { in the school. }\end{array}$ & 3.27 & Indecisive \\
\hline 45 & $\begin{array}{l}\text { Class representative, we will send our wishes, suggestions and } \\
\text { complaints to the relevant persons. }\end{array}$ & 3.25 & Indecisive \\
\hline \multirow[t]{2}{*}{46} & If I had a choice, I would choose this school again. & 3.11 & Indecisive \\
\hline & AVERAGE & 3.29 & Indecisive \\
\hline
\end{tabular}

Table 7 shows the most common characteristics of students they like in their schools; teachers (113), friendship environment (79), physical environment (68), nothing (47) and social equipments (35). Characteristics that pupils want to change at their school; new laboratories should be established (134), social activities should be increased (129), existing laboratories should be developed (68), food in the dining room should be beautified (57), building (52) and selective courses should be preferred by students (41). When asked about other things 
they want to tell students; (49), telephone collections (45), gymnasium construction (34), and social workshops (67), social activities should be increased (61), physical education lessons (52), smart boards should be opened and technological innovations in the laboratories (32) the library conditions were improved.

Table 7. Responses given to open-ended questions by students

\begin{tabular}{|l|l|}
\hline 47 & $\begin{array}{l}\text { What do you most like about our school: } \\
\text { Teachers (113), Friendship environment (79), Physical environment (68), Nothing (47) } \\
\text { and Social equipments (35) }\end{array}$ \\
\hline 48 & $\begin{array}{l}\text { What do you want your school to change? } \\
\text { Building new laboratories (134), Increasing social activities (129), Developing existing } \\
\text { laboratories (68), Cooking food in the dining room (57), Building (52) and Elective } \\
\text { courses according to the preferences of the students (41) }\end{array}$ \\
\hline 49 & $\begin{array}{l}\text { If there is anything else you want to mention, please do write: } \\
\text { (49), Phones collection (45), Sports hall (34), and Social sciences should be improved } \\
\text { (67), social activities should be increased (61) Improve library conditions (32) }\end{array}$ \\
\hline
\end{tabular}

3.3. Findings about the parents

A total of 142 parents joined the survey. The distribution of the parents by sex was found as male (105) and female (37). The distributions of parents by sex are shown in Table 8. Distribution of the parents according to their ages was found between 35-40 years (17), 40-45 years (113), 50-55 years (10) and over 55 years (2). The distribution of the parents according to their ages is shown in Table 9.

Table 8. Distribution of Parents by sex

\begin{tabular}{|l|l|}
\hline Gender & Frequency \\
\hline Men & 105 \\
\hline Women & 37 \\
\hline
\end{tabular}

Table 9. Distribution of Parents by age

\begin{tabular}{|l|l|}
\hline Age & Frequency \\
\hline $35-40$ years old & 17 \\
\hline $40-45$ years old & 113 \\
\hline $50-55$ & 10 \\
\hline 55 and over & 2 \\
\hline
\end{tabular}

Distribution of parents by salary is shown in Table 10. Less than 1000 TL (5), 1000-1500 TL (2), 1500-200 TL (12), 2000-2500 TL (5), 2500-3000 TL (7), 3000-3500 TL (15) 4000 TL (19), 4000-4500 TL (17), 4500-5000 TL (19), 5000-5500 TL (11), 5500-7500 TL (12), 7500-10000 TL (12) (4).

The distributions of parents by occupation are shown in Table 11. The parents who participated in the survey were found to be teachers (33), civil servants (26), shopkeepers (20), housewives (15), engineers (10), retirees (9), police (8), doctors and technicians (4), soldiers and lawyers (2), bankers, farmers, dentists, pharmacists, workers and veterinarians (1). 


\section{Macrothink

The distributions of the parents according to their educational levels are shown in Table 12 . The educational levels of the parents was determined as primary school (5), junior high school (6), high school (17), associate degree (14), undergraduate (70), graduate (23) and doctorate (7).

Table 10. Distribution of parents in salaries

\begin{tabular}{|l|l|}
\hline Salary & Frequency \\
\hline Less than $1000 \mathrm{TL}$ & 5 \\
\hline $1000-1500$ & 2 \\
\hline $1500-2000$ & 12 \\
\hline $2000-2500$ & 5 \\
\hline $2500-3000$ & 7 \\
\hline$\$ 3000-3500$ & 15 \\
\hline$\$ 3500-4000$ & 19 \\
\hline$\$ 4000-4500$ & 17 \\
\hline$\$ 4500-5000$ & 19 \\
\hline $5000-5500 \mathrm{TL}$ & 11 \\
\hline \$ 5500-7500 & 12 \\
\hline \$ 7500-10,000 & 12 \\
\hline 10,000 TL and over & 4 \\
\hline
\end{tabular}

Table 11. Distribution of Parents by occupation

\begin{tabular}{|l|l|}
\hline Job & Frequency \\
\hline Teacher & 33 \\
\hline Officer & 26 \\
\hline Craftsman & 20 \\
\hline Houswife & 15 \\
\hline Engineer & 10 \\
\hline Retired & 9 \\
\hline Policeman & 8 \\
\hline Doctor & 4 \\
\hline Technician & 4 \\
\hline Academician & 3 \\
\hline Soldier & 2 \\
\hline Lawyer & 2 \\
\hline Banker & 1 \\
\hline Farmer & 1 \\
\hline Dentist & 1 \\
\hline Pharmacist & 1 \\
\hline Worker & 1 \\
\hline Vet & 1 \\
\hline
\end{tabular}


Table 12. Distribution of Parents by educational status

\begin{tabular}{|l|l|}
\hline Education Level & Frequency \\
\hline Primary school & 5 \\
\hline Secondary school & 6 \\
\hline High school & 17 \\
\hline Associate degree & 14 \\
\hline Bachelor's degree & 70 \\
\hline Master Degree & 23 \\
\hline Ph.D & 7 \\
\hline
\end{tabular}

Parent satisfaction scale consists of 37 items with 5 likert type and 3 open ended questions. The average scores and satisfaction ratings of the answers given by parents to scale items are shown in Table 13. The avarage of the answers given by parents to the scale was determined as "Partially agree $(3,81)$ ". The responses to the scale items were determined to be indecisive (9), partially agree (19) and strongly agree (9). Answers to the open-ended questions on the satisfaction level of the Parents is shown in Table 14.

Table 13. Responses given by Parents to satisfaction scale

\begin{tabular}{|l|l|l|l|}
\hline I.N & \multicolumn{1}{|c|}{ Items } & X & $\begin{array}{l}\text { Parent } \\
\text { Satisfaction }\end{array}$ \\
\hline 1 & I can find the respondent when I call the phone & 4,38 & $\begin{array}{l}\text { Absolutely } \\
\text { agree }\end{array}$ \\
\hline 2 & $\begin{array}{l}\text { I can easily communicate with school administrators when I } \\
\text { need }\end{array}$ & 4,46 & Strongly agree \\
\hline 3 & I can easily communicate with school teachers when I need it & 4,37 & I strongly agree \\
\hline 4 & The other staff of the school respect us and behave gully. & 4,21 & $\begin{array}{l}\text { Absolutely } \\
\text { agree }\end{array}$ \\
\hline 5 & The notices that parents need to know are announced on time & 4,28 & Strongly agree \\
\hline 6 & I get advice from the school on the issues I need & 3,62 & Partially agree \\
\hline 7 & Parent meetings held by our school are efficient & 3,86 & Partially agree \\
\hline 8 & I can tell school my wishes and wishes about the school & 4,08 & Partially agree \\
\hline 9 & $\begin{array}{l}\text { My wishes and wishes that I have given to the school are } \\
\text { taken into consideration }\end{array}$ & 3,71 & Partly agree \\
\hline 10 & I have confidence in school administrators & 4,2 & Partially agree \\
\hline 11 & I have confidence in the teachers of the school & 4,3 & $\begin{array}{l}\text { Absolutely } \\
\text { agree }\end{array}$ \\
\hline 12 & I have confidence in other staff of the school & 4,06 & Partly agree \\
\hline 13 & $\begin{array}{l}\text { The student can get adequate guidance about course work } \\
\text { techniques. }\end{array}$ & 3,46 & Partially agree \\
\hline 14 & Students are informed about upper education institutions. & 3,7 & Partially agree \\
\hline 15 & The physical conditions of the school are sufficient & 3,01 & Indecisive \\
\hline 16 & The school has adequate security measures & 2,95 & Indecisive \\
\hline 17 & School road is safe & 2,86 & Indecisive \\
\hline
\end{tabular}




\begin{tabular}{|c|c|c|c|}
\hline 18 & I think that classroom sizes should be smaller. & 3,85 & Partially agree \\
\hline 19 & Parent representatives can represent all parents & 3,23 & Indecisive \\
\hline 20 & $\begin{array}{l}\text { Our views are taken into account in decisions that concern us } \\
\text { at school }\end{array}$ & 3,39 & Indecisive \\
\hline 21 & Our child can easily ask a teacher what he does not understand & 3,93 & Partly agree \\
\hline 22 & Our child can express opinions and suggestions easily in class & 4,03 & Partly agree \\
\hline 23 & Guidance is given to career decision making at school. & 3,48 & Partially agree \\
\hline 24 & The laboratories at school are sufficient. & 3,03 & Indecisive \\
\hline 25 & 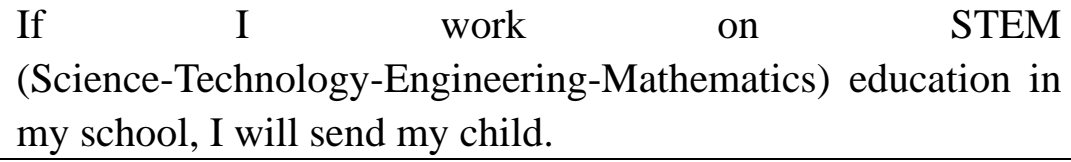 & 4.5 & $\begin{array}{l}\text { Absolutely } \\
\text { agree }\end{array}$ \\
\hline 26 & $\begin{array}{l}\text { I think that there must be laboratories in the school related to } \\
\text { your technology (robotics, automation, industry } 4.0 \text { and } \\
\text { manufacturing etc.). }\end{array}$ & 4.58 & $\begin{array}{l}\text { Absolutely } \\
\text { agree }\end{array}$ \\
\hline 27 & $\begin{array}{l}\text { I think that technological-based laboratories and classes } \\
\text { should be established in accordance with the projects to be } \\
\text { developed on behalf of the school. }\end{array}$ & 4.7 & $\begin{array}{l}\text { Absolutely } \\
\text { agree }\end{array}$ \\
\hline 28 & My child is happy to be in this school & 4.13 & Partly agree \\
\hline 29 & School is always clean and well maintained & 3.85 & Partially agree \\
\hline 30 & School board is always clean and well maintained & 3.25 & Indecisive \\
\hline 31 & School supplies in the canteen are clean and healthy & 3.75 & Partly agree \\
\hline 32 & Meals at school are clean and healthy & 3,4 & Indecisive \\
\hline 33 & Social and sports activities at the school are adequate & 3,13 & Indecisive \\
\hline 34 & My student socialized at school & 3,42 & Partially agree \\
\hline 35 & $\begin{array}{l}\text { I think that students are treated neutrally when evaluating } \\
\text { success }\end{array}$ & 4,04 & Partly agree \\
\hline 36 & The success of my student at the school is rewarded & 3,63 & Partially agree \\
\hline 37 & At school my student acquires a positive personality. & 3.96 & Partially agree \\
\hline & AVERAGE & 3.81 & Partially agree \\
\hline
\end{tabular}

Table 14. Answers to the open-ended questions on the satisfaction level of the Parents

\begin{tabular}{|l|l|}
\hline 38 & $\begin{array}{l}\text { What do you most like about our school: } \\
\text { Teachers and administrators (34), education (29), students and students (23), physical } \\
\text { conditions (21) }\end{array}$ \\
\hline 39 & $\begin{array}{l}\text { What do you want your school to change? } \\
\text { Improvement of laboratories (45), improvement of boarding conditions (21), } \\
\text { improvement or diversification of social facilities (19), improvement in cafeteria and } \\
\text { cook (16), improvement of physical conditions (13) }\end{array}$ \\
\hline 40 & $\begin{array}{l}\text { If There Is Anything You Want to Tell Please Write: } \\
\text { Increasing the number of elective courses and considering students' demands, acquiring } \\
\text { a sense of belonging, increasing group activities and types, facilitating transportation, } \\
\text { pension and school cleaning }\end{array}$ \\
\hline
\end{tabular}




\section{Results and Recomendations}

The average of teachers' responses to scale items was found to be "I strongly agree" $(4,41)$. When the answers to the teachers' scale items are examined, it is seen that they mark the "I strongly agree" and "I agree" options. This shows us that the satisfaction level of the teachers is high. Teachers like the level of student achievement and quality most in their schools. Teachers then expressed their preference for physical conditions and social activities, respectively. Teachers want to change the physical conditions in their schools and improve the laboratories. Teachers think that extracurricular cultural and sporting activities should be formed at the beginning of the thoughts for increasing academic and social conditions. Almost all of the teachers want to establish an innovative class / laboratory such as marker lab 4.0 in their schools. Teachers also indicate that guidance activities should be increased and Foreign Language lesson hours should be increased.

The average of the answers given by the students to the scale items was found as "Indecisive" (3.29). I have found that 2 items that pupils definitely participate in are "I want to organize festivals that become traditional in terms of the formation of school culture" and "I think that there should be laboratories related to technology of the future (robotics, automation, industry 4.0 and manufacturing etc.) in our school". The items that students do not participate in are found to be "The physical conditions of our school are sufficient", "The laboratories in our school are sufficient", "Social and cultural activities are organized in the school as much as possible" and " Students stated that they most liked the environment of teachers and friendship in their schools. Students want new laboratories to be established, social activities to be improved and existing laboratories to be improved. They also stated that students should not be given too much homework, that there should be Physical Education classes, that smart boards should be used, and that phones should not be collected.

The average response of the respondents to the scale items was found to be "Partly agree" $(3,81)$. What parents most like are teachers and administrators, education, students and student levels. They expect those concerned to develop laboratories, improve boarding conditions, improve social facilities, improve cafeterias and cooks, and improve physical conditions. They also think that among science schools, the joint lab experiment exams should be carried out, the social and sporting activities should be increased, the elective course should be in accordance with the student demands, the sense of belonging should be made, the transportation should be facilitated and the host-school cleanliness should be improved.

In line with the opinions of teachers, students and parents; to improve the physical conditions of the schools, to improve the laboratories, to improve the board and the dining hall, to create cultural and sportive activities, to motivate the students, to carry out joint practice exams, to establish laboratories for new professions and to increase the guidance activities are some of the issues put forward. In this direction, the existing laboratories should be updated with technological developments and Marker Lab., Industry 4.0 etc. establishment of innovative classes / laboratories is recommended. Improvement of the food in the dining hall and students views regarding this should take into account. The conditions of the hostel should be improved. Social and sports activities should be given priority. Increase of business cooperation between science high schools, joint exams between students, social and sport 
activities should be organized. Institutional culture should be developed and a sense of belonging should be gained.

\section{References}

Aldridge, J. M., \& Fraser, B. J. (2016). Teachers' views of their school climate and its relationship with teacher self-efficacy and job satisfaction. Learning Environments Research, 19(2), 291-307.

Aydın, İ. (2004). Okul çevre ilişkileri, ĕgitim ve okul yöneticiliği’’.Editör: Yüksel Özden, Ankara: Pegem A Yayıncılık

Balc1, A. (2013). Etkili okul, okul geliştirme. Ankara: PegemA Yayıncılık

Barbra, Z. E. (2006). Georgia school principals' perceptions of the impact of school facilities on student achievement. Doctoral Dissertation, Georgia Southern University, Statesboro, Georgia.

Başar, H. (2014). Sınıf Yönetimi. Ankara: Anı Yayıncılık.

Bullock, C. C. (2007). The relationship between school building conditions and student achievement at the middle school level in the commonwealth of Virginia. Doctoral Dissertation, Virginia Polytechnic Institute and State University, Blacksburg, Virginia

Corcoran, T., White, J., \& Whitburn, B. (Eds.). (2015). Disability studies: Educating for inclusion. Springer.

Çınkır, Ş., \& Nayır, F. (2017). Okul aile işbirliği standartlarına ilişkin veli görüşlerinin incelenmesi- Examining parent opinions about school-parents cooperation standards. Hacettepe Üniversitesi Eğitim Fakültesi Dergisi (H. U. Journal of Education) 32(1): 245-264

Dean, A., \& Gibbs, P. (2015). Student satisfaction or happiness? A preliminary rethink of what is important. Quality Assurance in Education, 23(1), 5-19.

Douglas, J., McClelland, R., \& Davies, J. (2008). The development of a conceptual model of student satisfaction with their experience in higher education. Quality assurance in education, 16(1), 19-35.

Göktaş, Z. (2007). Balıkesir ilindeki beden eğitimi öğretmenlerinin iş doyumu ve bazı değişkenlerle olan ilişkisinin incelenmesi. Niğde Üniversitesi Beden Ĕ̈itimi ve Spor Bilimleri Dergisi, 1(1).

Hargreaves, D. (2012). The challenge for the comprehensive school: culture, curriculum and community. Routledge.

Karasar, N. (2007). Bilimsel araştırma yöntemleri. Ankara: Nobel Yayınevi

Özden, Y. (2010). Eğitimde yeni değerler. Ankara: PegemA Yayıncılık

Özgüven, İ. E. (1994). Psikolojik testler. Ankara: Yeni Doğuş Matbaası.

Schleicher, A. (2015). Schools for 21st-century learners: Strong leaders, confident teachers, innovative approaches. International Summit on the Teaching Profession. OECD Publishing. 2, rue Andre Pascal, F-75775 Paris Cedex 16, France.

Shann, M. H. (1998). Professional commitment and satisfaction among urban middle schools. The Journal of Educational Research, 92(2), 67-73. 
Sulak, S. A. (2016). Okul sağlığı ve güvenliği. E. Yılmaz, M. Çalışkan \& S. A. Sulak (Ed.), Eğitim bilimlerinden yansımalar, (ss.45-57). Konya: Çizgi Kitabevi

Y1lmaz, E., \& Y1ldırım, A. (2017). Study of the academic optimism levels of the teachers in terms of certain variables Öğretmenlerin akademik iyimserlik düzeylerinin bazı değişkenler açısından incelenmesi. Journal of Human Sciences, 14(2), 1215-1224.

Zehir, C., Erdogan, E., \& Basar, D. (2011). The relationship among charismatic leadership, ethical climate, job satisfaction and organizational commitment in companies. Journal of Global Strategic Management, 10, 49-59.

\section{Copyright Disclaimer}

Copyright reserved by the author(s).

This article is an open-access article distributed under the terms and conditions of the Creative Commons Attribution license (http://creativecommons.org/licenses/by/3.0/). 